\title{
GENERALIZED MUSCULAR HYPERTONICITY ASSOCIATED WITH GENERAL ANAESTHESIA: A SUGGESTED ANAESTHETIC MANAGEMENT
}

\author{
J. E. S. RgLTON, M.B., F.F.A.R.C.s.(ENG.), R. E. CRETGHTON, M.D., F.R.C.P.(c), \\ A. W. CoNN, M.D., F.R.C.P.(C), AND S. NABETA, M.D., F.R.C.P.(C) ${ }^{*}$
}

RECENT REPORTS ${ }^{1-5}$ have drawn attention to the problem of generalized muscular hypertonicity and hyperpyrexia associated with general anaesthesia. "This [muscular] rigidity appeared as an abnormal response to a usual dose of succinylcholine in those patients who received this drug, and at a later stage in the course of anaesthesia in those who did not." 8

This paper describes a case in which generalized muscular hypertonicity followed the administration of succinylcholine and subsequently an alternative anaesthetic technique was employed successfully.

\section{Case Repont}

A healthy 12-year-old female (wt. $29 \mathrm{~kg}$.) was admitted with a diagnosis of idiopathic thoraco-lumbar scoliosis. She had previously been treated conservatively and was now scheduled for spinal fusion and Harrington rod instrumentation. There was no previous history of anaesthesia or surgery.

On the day of operation, meperidine $(45 \mathrm{mg}$.) and atropine $(0.6 \mathrm{mg}$.) were given intramuscularly 45 minutes preoperatively. Anaesthesia was induced with sodium thiopentone (125 mg.). Succinylcholine (30 mg. i.v.) was given to facilitate intubation. No muscle fasciculations were observed, but instead of the expected relaxation, a generalized muscular hypertonicity occurred. An additional dose of succinylcholine $(20 \mathrm{mg}$.) produced no reduction in the degree of rigidity.

Intubation with a Portex tube $(6.0 \mathrm{~mm}$.) was carried out with some difficulty and the patient was ventilated with a nitrous oxide and oxygen mixture. Spontaneous respiratory efforts returned within ten minutes of induction. In view of the persisting hypertonicity, d-tubocurarine ( $12 \mathrm{mg}$.) was administered, but no generalized muscle relaxation became apparent, although spontaneous respiration ceased. Surgery was deferred and close observation of the patient's vital signs and blood chemistry was continued. Her blood pressure rose from 110 systolic to 140 , and her pulse rate from 120 to 160 per minute during the first thirty minutes of anaesthesia and remained elevated for ninety minutes. A nerve stimulator (B. W. "Block-Aid Monitor") was applied to the ulnar nerve using needle electrodes. There was no response to twitch or tetanus stimulation.

Eighty minutes after induction, spontaneous respiratory efforts recommenced and ulnar nerve stimulation indicated fade and facilitation. Ventilation with

-Department of Anaesthesia, University of Toronto, and the Hospital for Sick Children, Toronto, Ontario. 
oxygen was continued for an additional forty minutes, at which time the muscular rigidity disappeared and the response to ulnar nerve stimulation was normal. The nitrous oxide was discontinued and the patient awoke. When spontaneous respiration was considered adequate the endotracheal tube was removed and the patient returned to the recovery room. Her subsequent progress was uneventful.

The blood gas analyses and body temperature changes recorded are shown in Table I. Rectal temperature and muscle temperature recordings paralleled the oesophageal changes. Arterialized capillary blood was used for the $\mathrm{pH}$ and gas determinations.

TABLE I

\begin{tabular}{|c|c|c|c|c|c|c|}
\hline Time & $\begin{array}{l}\text { Oesophageal } \\
\text { temperature } \\
\left({ }^{\circ} \mathrm{C} .\right)\end{array}$ & $\mathrm{pH}$ & $\underset{(\mathrm{mm} . \mathrm{Hg})}{\mathrm{Pco}_{2}}$ & $\begin{array}{c}\text { Base } \\
\text { excess } \\
\text { (m.Eq./L.) }\end{array}$ & $\underset{(\mathrm{mm} . \mathrm{Hg})}{\mathrm{Po}_{\mathrm{g}}}$ & Comments \\
\hline $\begin{array}{l}\text { Induction } \\
\text { At } 12 \mathrm{~min} . \\
\text { At } 18 \mathrm{~min} . \\
\text { At } 28 \mathrm{~min} .\end{array}$ & $\begin{array}{l}37.5 \\
37.7 \\
37.8\end{array}$ & & & & & $\begin{array}{l}\text { D-tubocurarine } 12 \mathrm{mg} \text {. } \\
\text { Highest temperature } \\
\text { recorded }\end{array}$ \\
\hline At $57 \mathrm{~min}$. & 36.7 & 7.04 & 90 & -9 & 115 & $\begin{array}{l}\text { Blood sugar } 145 \mathrm{mg} . \% \\
\text { B.U.N. } 12 \mathrm{mg} . \% \\
\text { THAM } 100 \mathrm{ml} .0 .6 M \\
\text { solution }\end{array}$ \\
\hline $\begin{array}{l}\text { At } 1 \mathrm{hr} .35 \mathrm{~min} . \\
\text { At } 2 \mathrm{hr} .18 \mathrm{~min} . \\
\text { At } 5 \mathrm{hr} .28 \mathrm{~min} .\end{array}$ & $\begin{array}{l}37.1 \\
37.0 \\
36.8\end{array}$ & $\begin{array}{l}7.04 \\
7.28 \\
7.37\end{array}$ & $\begin{array}{c}100^{*} \\
63 \\
55\end{array}$ & $\begin{array}{l}-6 \\
+0.5 \\
+5\end{array}$ & $\begin{array}{r}370 \\
84\end{array}$ & $\begin{array}{l}\text { After hyperventilation } \\
\text { Spontaneous ventilation } \\
\text { on air }\end{array}$ \\
\hline
\end{tabular}

*The marked rise in $\mathrm{PCO}_{2}$ occurred in spite of artificial ventilation.

The generalized muscular hypertonicity as a response to general anaesthetic agents and muscle relaxants was thought to be similar to cases previously reported. ${ }^{1}$ The body temperature changes in this case were minimal, and it was not possible to be certain that hyperpyrexia would have occurred, since no additional anaesthetic agents were administered.

It was essential to proceed with the operation as the scoliosis was progressive. An alternative anaesthetic technique was selected. For the second anaesthetic, barbiturates, muscle relaxants, and inhalational agents other than nitrous oxide were omitted. An intravenous infusion of lactated Ringer's solution was established. Atropine (0.3 mg.) and meperidine ( $25 \mathrm{mg}$.) were given intravenously, and anaesthesia was induced with nitrous oxide and oxygen (9:3.5 L./min.) using a face mask and Ayre's T-piece circuit.

As induction proceeded, $10 \mathrm{mg}$, increments of meperidine were given intravenously up to $60 \mathrm{mg}$. Thirty minutes after induction, a cuffed Portex endotracheal tube was inserted without difficulty.

Anaesthesia was continued with nitrous-oxide-oxygen and controlled hyperventilation by means of a pressure limited ventilator. The patient was transferred to a scoliosis operating frame. ${ }^{7}$ The operative procedure lasted three and a quarter hours, during which time the nitrous-oxide-oxygen hyperventilation 
anaesthesia was supplemented by intermittent doses of meperidine (total dose $90 \mathrm{mg}$.).

At no time during the induction or maintenance of anaesthesia was there any evidence of increased muscle tone. Electrical stimulation of the ulnar nerve showed a normal response to twitch and tetanus throughout the procedure. The blood gas analyses and body temperatures recorded are shown in Table II.

TABLE II

\begin{tabular}{|c|c|c|c|c|c|c|}
\hline Time & $\underset{\substack{\text { Rectal } \\
\text { temperature } \\
\left({ }^{\circ} \mathrm{C} .\right)}}{ }$ & pH & $\underset{(\mathrm{mm} . \mathrm{Hg})}{\mathrm{Pco}_{2}}$ & $\begin{array}{c}\text { Base } \\
\text { excess } \\
\text { (m.Eq./L.) }\end{array}$ & $\underset{(\mathrm{mm} . \mathrm{Hg})}{\mathrm{Pog}}$ & Comments \\
\hline $\begin{array}{l}\text { Induction } \\
\text { At } 15 \mathrm{~min} \text {. } \\
\text { At } 45 \mathrm{~min} . \\
\text { At } 1 \mathrm{hr} .15 \mathrm{~min} \text {. } \\
\text { At } 1 \mathrm{hr} .45 \mathrm{~min} \text {. } \\
\text { At } 2 \mathrm{hr} .15 \mathrm{~min} \text {. } \\
\text { At } 2 \mathrm{hr} .45 \mathrm{~min} \text {. } \\
\text { At } 3 \mathrm{hr} .15 \mathrm{~min} \text {. } \\
\text { At } 3 \mathrm{hr} .45 \mathrm{~min} \text {. }\end{array}$ & $\begin{array}{l}37.2 \\
37.0 \\
36.7 \\
35.0 \\
34.8 \\
34.8 \\
34.5 \\
34.4 \\
\mathbf{3 4 . 5}\end{array}$ & $\begin{array}{l}7.48 \\
7.42 \\
7.40 \\
7.41 \\
7.41\end{array}$ & $\begin{array}{l}25 \\
26 \\
26.5 \\
25.5 \\
26.5\end{array}$ & $\begin{array}{l}-3 \\
-6 \\
-7 \\
-6.5 \\
-6.5\end{array}$ & $\begin{array}{r}114 \\
125 \\
97 \\
106 \\
119\end{array}$ & $\begin{array}{l}\mathrm{Na}, 137 ; \mathrm{Cl}, 102: \mathrm{K}, 4 \\
\text { Operation completed }\end{array}$ \\
\hline
\end{tabular}

The progressive fall in body temperature is a normal response to prolonged controlled hyperventilation with the patient positioned on the scoliosis operating frame. The ambient temperature was $68^{\circ} \mathrm{C}$., the relative humidity 70 per cent.

The measured blood loss from the operative site was $750 \mathrm{ml}$., and a further $250 \mathrm{ml}$. was taken for biochemical analysis. Stored blood was given to replace these losses and may have contributed to the mild increase in metabolic acidosis. Lactated Ringer's solution ( $700 \mathrm{ml}$.$) and dextrose 5$ per cent $(130 \mathrm{ml}$.) were also given during operation.

The patient returned to the recovery room in good condition and made an uneventful recovery.

\section{Discussion}

This patient's response to succinylcholine was similar to that shown by cases previously reported, ${ }^{1}$ but the muscular hypertonicity was not followed by hyperpyrexia. It is impossible to say whether a marked rise in body temperature would have occurred if anaesthesia had continued with more potent agents.

The alternative anaesthetic technique consisting of $\mathrm{N}_{2} \mathrm{O} / \mathrm{O}_{2}$ /meperidine and controlled hyperventilation was free from complications. There was no evidence of an abnormal muscular response.

Safe, acceptable conditions were provided for surgery in circumstances where regional anaesthesia was inappropriate.

\section{ACKNOWLEDGMENT}

The authors would like to thank Dr. John Hall for permission to publish details of this case. 


\section{REFERENCES}

1. Relton, J. E. S.; Cretcrton, R. E.; Johnston, A. E.; Pelton, D. A.; Conn, A. W. Hyperpyrexia in Association with General Anaesthesia in Children. Canad. Anaesth. Soc. J. 13: 419 (1966).

2. Thut, W. H. \& Davenport, H. T. Hyperpyrexia Associated with Succinylcholine-Induced Muscle Rigidity: A Case Report. Canad. Anaesth. Soc. J. 13: 425 (1966).

3. Hogc, S. \& Renwick, W. Hyperpyrexia during Anaesthesia. Canad. Anaesth. Soc. J. 13: $429(1966)$.

4. LavoiE, G. Hyperpyrexia during General Anaesthesia: A Case Report. Canad. Anaesth. Soc. J. 13: 444 (1966).

5. Davies, L. E. \& Graves, H. B. Hyperpyrexia and Death Associated with General Anaesthesia. Canad. Anaesth. Soc. J. 13: 447 (1966).

6. Malignant Hyperpyrexia during General Anaesthesia. Editorial. Canad. Anaesth. Soc. J. 13: 415 (1966).

7. Relton, J. E. S, \& Hall, J. E. Reduction of Haemorrhage during Spinal Fusion and Internal Metallic Fixation Using a New Scoliosis Operating Frame. Brit. J. Bone Jt. Surg. (In press.) 